\title{
Gene expression in oligodendroglial tumors
}

\author{
Elisabeth J. Shaw ${ }^{\mathrm{a}, *}$, Brian Haylock ${ }^{\mathrm{b}}$, David Husband ${ }^{\mathrm{b}}$, Daniel du Plessis ${ }^{\mathrm{c}}$, D. Ross Sibson ${ }^{\mathrm{a}}$, \\ Peter C. Warnke ${ }^{\mathrm{d}}$ and Carol Walker ${ }^{\mathrm{a}}$ \\ ${ }^{a}$ School of Cancer Studies, University of Liverpool, Liverpool, UK \\ ${ }^{\mathrm{b}}$ Clatterbridge Centre for Oncology, Clatterbridge Hospital, Bebington, Wirral, UK \\ ${ }^{\mathrm{c}}$ Salford Royal Hospital and Clinical Neurosciences Research Group, University of Manchester, Manchester, UK \\ d Department of Neurosurgery, Beth Israel Deaconess Medical Center, Harvard Medical School, Boston, MA, USA
}

\begin{abstract}
Background: Oligodendroglial tumors with 1p/19q loss are more likely to be chemosensitive and have longer survival than those with intact $1 \mathrm{p} / 19 \mathrm{q}$, but not all respond to chemotherapy, warranting investigation of the biological basis of chemosensitivity.

Methods: Gene expression profiling was performed using amplified antisense RNA from 28 oligodendroglial tumors treated with chemotherapy (26 serial stereotactic biopsy, 2 resection). Expression of differentially expressed genes was validated by real-time PCR.

Results: Unsupervised hierarchical clustering showed clustering of multiple samples from the same case in 14/17 cases and identified subgroups associated with tumor grade and 1p/19q status. 176 genes were differentially expressed, 164 being associated with $1 \mathrm{p} / 19 \mathrm{q}$ loss $(86 \%$ not on $1 \mathrm{p}$ or $19 \mathrm{q}) .94$ genes differed between responders and non-responders to chemotherapy; 12 were not associated with $1 \mathrm{p} / 19 \mathrm{q}$ loss. Significant differential expression was confirmed in 11/13 selected genes. Novel genes associated with response to therapy included SSBP2, GFRA1, FAP and RASD1. IQGAP1, INA, TGIF1, NR2F2 and MYCBP were differentially expressed in oligodendroglial tumors with $1 \mathrm{p} / 19 \mathrm{q}$ loss.

Conclusion: Gene expression profiling using serial stereotactic biopsies indicated greater homogeneity within tumors than between tumors. Genes associated with $1 \mathrm{p} / 19 \mathrm{q}$ status or response were identified warranting further elucidation of their role in oligodendroglial tumors.
\end{abstract}

Keywords: Oligodendroglioma, gene expression, chemosensitivity

Abbreviations

WHO World Health Organization;

OII oligodendroglioma grade II;

OIII oligodendroglioma grade III;

OAII oligoastrocytoma grade II;

OAIII oligoastrocytoma grade III;

$\mathrm{PCV}$ procarbazine, lomustine $(\mathrm{CCNU})$ and vincristine;

CR complete response;

PR partial response;

MR minor response;

PD progressive disease;

SD stable disease;

HPRT hypoxanthyl-phosphoribosyl transferase;

\footnotetext{
*Corresponding author: Dr. Elisabeth Shaw, Cancer Research Centre, School of Cancer Studies, University of Liverpool, 200 London Road, Liverpool, L3 9TA, UK. Tel.: +44 151794 8862; Fax: +44 151794 8925; E-mail: e.j.shaw@liverpool.ac.uk.
}

aRNA antisense RNA;

PCA principle component analysis;

SAM significance analysis of microarrays;

FDR false discovery rate;

ECACC European Collection of Cell Cultures.

\section{Introduction}

Oligodendrogliomas, constituting $5-25 \%$ of gliomas, have a better prognosis and are more likely to be chemosensitive than other gliomas $[9,41]$. Combined loss of chromosomal arms $1 \mathrm{p}$ and $19 \mathrm{q}$ is frequently found in oligodendrogliomas and 30-60\% of oligoastrocytomas and is now considered their molecular hallmark $[9,28,43]$. In 1998 1p/19q loss was associated with chemotherapeutic response and longer recurrence-free survival in anaplastic oligodendrogliomas [2]. Further studies have confirmed that most anaplastic oligodendrogliomas and oligoastrocytomas with these genetic losses respond to chemother- 
apy and are more likely to have a good prognosis as well as longer progression-free and overall survival $[13,39,40,45]$. In low grade oligodendroglial tumours $1 \mathrm{p} / 19 \mathrm{q}$ loss is associated with prolonged survival but associations between these genetic losses and response to therapy are more controversial [21]. Irrespective of histopathology grade, some tumors with $1 \mathrm{p} / 19 \mathrm{q}$ loss fail to respond to therapy, while some without these losses also benefit from chemotherapy and show improved survival $[2,13,40,45]$. A more effective means to predict those patients likely to benefit from chemotherapy is needed. Additionally, the biological basis of response to therapy and the improved prognosis of tumors with $1 \mathrm{p} / 19 \mathrm{q}$ loss are poorly understood, warranting further investigation.

In gliomas, distinct gene expression profiles have been associated with tumor grade, histology, survival $[11,32,46,48]$, and molecular genetics [6,24,25, $35]$, and in oligodendrogliomas with $1 \mathrm{p} / 19 \mathrm{q}$ loss and therapeutic response $[6,7]$. These studies investigated mainly anaplastic oligodendrogliomas and, as with the majority of gene expression studies, analyzed tumor samples snap frozen following surgical resection making radiological evaluations of therapeutic response difficult. We have reported previously that $1 p / 19 q$ loss was significantly associated with response to PCV chemotherapy and prolonged survival in a single centre study of oligodendrogliomas and oligoastrocytomas, grades II and III [45]. In this series the majority of cases were diagnosed by serial stereotactic biopsy which provides small samples $\left(<1 \mathrm{~mm}^{3}\right)$ for molecular analysis and allows study of treatment response without surgical artifacts. This study was undertaken to determine whether expression profiling could be performed using serial stereotactic biopsy samples and to identify genes associated with $1 \mathrm{p} / 19 \mathrm{q}$ loss and chemosensitivity.

\section{Material and methods}

\subsection{Clinical samples}

Tumor samples, obtained from the Walton Centre for Neurology and Neurosurgery were from a larger series of consecutive patients treated with chemotherapy at the Clatterbridge Centre for Oncology between May 2000 and July 2003 [43,45]. Inclusion in this study required snap frozen tumor tissue with $>50 \%$ tumor content, taken at surgery immediately prior to chemotherapy, to be available. The clinical characteristics of the 28 cases are given in Table 1 . The study had full ethical
Table 1

Clinical series

\begin{tabular}{lc}
\hline Age, years (median, range) & $44,22-71$ \\
Gender (Male : Female) & $18: 10$ \\
Surgery (Serial stereotactic biopsy : Resection) & $26: 2$ \\
Histopathology 1p/19q loss (yes : no) & \\
$\quad$ Oligodendroglioma WHO II & $4: 5$ \\
Oligoastrocytoma WHO II & $2: 3$ \\
Oligodendroglioma WHO III & $6: 0$ \\
Oligoastrocytoma WHO III & $2: 6$ \\
PCV given to: & 19 \\
Newly diagnosed, primary tumors & 8 \\
Recurrent tumors following radiotherapy & \\
Recurrent tumors following & 1 \\
radiotherapy and chemotherapy & \\
Response (yes : no) & $14: 0$ \\
1p/19q loss & $2: 11$ \\
1p/19q intact & 1 \\
Response unknown
\end{tabular}

approval and informed consent was obtained from all patients. Two tumors were resected and H\&E stained sections of frozen tissue were used to assess the pathology prior to RNA extraction. Twenty-six were sampled by frame-based, CT MRI-guided serial stereotactic biopsy performed as described previously [14], in which samples $\left(<1 \mathrm{~mm}^{3}\right)$ are taken along a stereotactic trajectory calculated to encompass the most aggressive part of the tumor as defined by contrast enhancement or in non-enhancing cases, to maximize representation of the tumor. Further details are given in the Supplementary Information (http://www.qub.ac.uk/isco/JCO). Alternate samples were taken for intra-operative smear diagnosis, formalin fixation/paraffin-embedding and immediate embedding in OCT and snap freezing in theatre.

As in Grasbon-Frodl et al. [8], pathology assessment of snap frozen stereotactic biopsies was based on the adjacent flanking biopsies which were formalin fixed, paraffin-embedded samples or intraoperative smear preparations. Samples representative of the histopathology diagnosis with solid tumor (where possible) were selected. p53 mutations (exons 5-8) and allelic imbalance of 1p36,19q13,17p13,10p12-10p15 and $10 \mathrm{q} 22-10 \mathrm{q} 26$ (assessed by microsatellite markers) was reported previously $[43,45]$. Tumors reported to have $1 \mathrm{p} / 19 \mathrm{q}$ loss had loss of all informative microsatellite markers tested at both $1 \mathrm{p} 36$ and 19q13 [43, 44]. Five tumors had loss of chromosome 10, including 2 with $1 \mathrm{p} / 19 \mathrm{q}$ loss, 10 tumors had loss of $17 \mathrm{p} 13$ (one with $1 \mathrm{p} / 19 \mathrm{q}$ loss) and 10 tumors had mutations in $\mathrm{p} 53$ (one with $1 \mathrm{p} / 19 \mathrm{q}$ loss). 
Clinical data was collated prospectively and response to chemotherapy assessed as described previously [45]. For 27 patients PCV was administered according to standard clinical protocols [17]. Lomustine $(\mathrm{CCNU})\left(110 \mathrm{mg} / \mathrm{m}^{2}\right)$ was given on day 1 , procarbazine $\left(60 \mathrm{mg} / \mathrm{m}^{2}\right)$ on days $8-21$ and vincristine $\left(1.4 \mathrm{mg} / \mathrm{m}^{2}\right.$ (maximum $2 \mathrm{mg}$ )) on days 8 and 29. Cycles were repeated every 6 weeks for a maximum of six cycles. The patients in this subset of our original study [45] received a median of 4 cycles of PCV. One case (an OIII with loss) included in this study was eligible for PCV chemotherapy but for patientrelated reasons was given CCNU only to which he showed a partial response. Response to chemotherapy was assessed by a consultant neuroradiologist blinded to genotype and other clinicopathological factors who reviewed all available MR or CT images taken before, during and after chemotherapy, and at follow-up. As far as clinically practical scans during therapy were after the 1st and 4th cycles of chemotherapy, at the end of chemotherapy and 3 months following chemotherapy. The largest perpendicular diameters of the tumor were measured in axial sections of T2-weighted MR images or contrast-enhanced regions in T1-weighted MR or CT images. Response was assessed using Macdonald criteria [22] for enhancing cases. For non-enhancing cases or those for whom contrast enhancement was not assessable, response was based on T2-weighted images. Response categories included: CR - Complete Response (disappearance of all tumor, off steroids and neurologically stable or improved); PR - Partial Response $(50 \%$ or greater reduction in cross-sectional area, steroids stable or reduced, and neurologically stable or improved); MR - Minor Response ( $>25-<50 \%$ reduction in cross-sectional area, steroids stable or reduced, and neurologically stable or improved); PD Progressive Disease (25\% or greater increase in cross sectional area or any new tumor on CT/MR images and/or neurologically worse with steroids stable or increased); SD - Stable Disease (all other situations). Cases were considered responders if they were CR, PR or MR and non-responders were SD and PD.

Four non-neoplastic brain samples (2 BD Premium Total RNA Whole Brain samples (BD Biosciences), 2 snap frozen temporal lobectomies from epilepsy surgery) and the glioblastoma cell line U373 (ECACC) were included. Universal Human Reference RNA (Stratagene) was used as a common reference in array hybridizations.

\subsection{RNA isolation}

RNA was extracted from tissues (biopsies or $10 \times$ $30 \mu \mathrm{m}$ cryostat sections of resections) or U373 cells using Strataprep ${ }^{\circledR}$ Total RNA Microprep Kit or Total RNA Miniprep Kit (Stratagene) respectively. RNA samples were quantified using the 'low range' assay and RiboGreen RNA Quantitation Kit (Molecular Probes). RNA quality was assessed using an Agilent 2100 Bioanalyzer (Agilent Technologies).

\subsection{Preparation and labeling of amplified RNA}

Total RNA (50 ng) was reverse transcribed using a modification of the strand switching SMART RT protocol with an oligo-dT primer containing a T7 RNA polymerase promoter, a primer containing the SMART $^{\mathrm{TM}}$ sequence (Clontech Laboratories Inc.) and Powerscript reverse transcriptase (BD Biosciences). Double stranded cDNA was generated using a $5^{\prime}$ primer containing the SMART ${ }^{\mathrm{TM}}$ sequence and Advantage Polymerase (BD Biosciences) and subjected to $\mathrm{T} 7$ in vitro transcription using MegaScript ${ }^{\circledR}$ (Ambion). A second round of amplification was performed priming $500 \mathrm{ng}$ antisense RNA (aRNA) with the $5^{\prime}$ sequence specific primer for first strand synthesis. Amino-allyl UTP was incorporated during the second round T7 in vitro transcription and RNA labeled with cy3 or cy5 (Amersham). Dye incorporation was calculated following aRNA purification using RNeasy ${ }^{\mathrm{TM}}$ mini kit (Qiagen) and ethanol precipitation. Labeled test and reference samples were combined and fragmented before competitive hybridization.

\subsection{Microarray hybridization and data analysis}

Oligonucleotide arrays containing 18,861 oligonucleotide probes (60 mers, average $3^{\prime}$ distance 397 bases (Compugen/Sigma-Genosys)) spotted in duplicate, printed over two slides (Hs_SGC_Av1 and Hs_SGC_Bv1), were provided by the Human Genome Mapping Project (Cambridge, UK). Hybridizations of test and reference labeled RNA were performed and a set of reliable probes generated (Supplementary Information; http://www.qub.ac.uk/isco/JCO).

Data analysis including Principle Component Analysis (PCA) and hierarchical clustering (Pearson correlation and average linkage) were performed in GeneSpring GX7.1 (Agilent Technologies). Differentially expressed genes with $\geqslant 2$ fold change were identified between tumors with or without $1 \mathrm{p} / 19 \mathrm{q}$ loss, and re- 
sponders or non-responders to chemotherapy (Welch's $t$-test). The Benjamini and Hochberg correction for multiple testing was applied and genes with a corrected $p$-value $<0.05$ were considered significant. Differentially expressed genes were also identified using the Significance Analysis of Microarrays algorithm (SAM) [37]. A false discovery rate (FDR) of $<5 \%$ was applied with fold change $\geqslant 2$. Those genes identified by both methods were reported as differentially expressed. Functional analysis was performed using Onto-Express [5] to assign genes to function and biological process categories.

\subsection{Quantitative PCR}

Quantitative real-time PCR was performed using 27 samples from 21 cases. First strand cDNA synthesis was performed in duplicate with $50 \mathrm{ng}$ of total RNA using Superscript ${ }^{\mathrm{TM}}$ III Reverse Transcriptase (Invitrogen) primed with oligo-dT (100 pmoles, Eurogentec). PCR was carried out in duplicate in $20 \mu \mathrm{l}$ reactions containing: $1 \times$ iQ SYBR Green Supermix (Bio-Rad Laboratories), $1 \mu \mathrm{M}$ each primer and $5 \mu \mathrm{l} 20$-fold diluted cDNA using an iCycler (Bio-Rad Laboratories); primer sequences and cycling conditions (Suppl. Information Table 1S: http://www.qub.ac.uk/isco/JCO). Relative expression levels were compared using the comparative $\mathrm{C}_{t}$ method $\left(2^{-\Delta \Delta \mathrm{C}_{T}}\right)$ [20] with sample measurements normalized to HPRT expression and reported relative to Human Reference RNA.

\section{Results}

\subsection{Gene expression profiling}

Total RNA extracted from clinical samples varied in yield (median $490 \mathrm{ng}$ (range 51-1913 ng)), but was of good quality regardless of sample size. Following a two round amplification procedure amplified aRNA had fragment lengths from 200-1500 bases and $\mathrm{A}_{260} / \mathrm{A}_{280}$ ratios of at least two. At least one clinical sample from each case showed successful amplification; 17 cases had multiple samples amplified.

Following quality control, data analysis was performed using 3719 and 3082 reliable probes from Hs_SGC_Av1 and Hs_SGC_Bv1 arrays respectively. Unsupervised hierarchical clustering was used to cluster samples according to the similarity of their gene expression profile (Fig. 1). The U373 cell line clustered independently from tissues; all four non-neoplastic brain samples clustered together. Of the 16 cases with two samples analyzed, 13 cases $(81 \%)$ showed samples clustering together. One case with three samples analyzed showed two biopsies clustering together. Failure of multiple biopsies from these cases to cluster together could not be accounted for by histological features evident on histopathological examination of flanking biopsies. A number of subgroups could be identified. Group 1 (G1) and Group 2 (G2) consisted of tumors that were mostly low-grade; those in G1 had 1p/19q loss whereas those in G2 did not. Group 3 (G3) and Group 4 (G4) were all high-grade tumors with (G3) or without (G4) 1p/19q loss. Group 5 (G5), consisted of all non-neoplastic brain samples and five tumor samples, of mixed grade, with intact $1 \mathrm{p} / 19 \mathrm{q}$. Response correlated with $1 \mathrm{p} / 19 \mathrm{q}$ loss $(p<0.0005)$ but did not further clarify the subgroups. No other clinical information (contrast enhancement or survival) or available molecular information (p53 mutation, chromosome 10 loss or $17 \mathrm{p} 13$ loss) was associated with distinct clusters. The study included: 19 primary untreated tumors of which 11 responded to therapy with 10 responders and no nonresponders having loss of $1 \mathrm{p} / 19 \mathrm{q} ; 8$ recurrent tumors previously treated with radiotherapy of which 4 with $1 \mathrm{p} / 19 \mathrm{q}$ loss responded to therapy and 4 with intact $1 \mathrm{p} / 19 \mathrm{q}$ did not; and one recurrent tumor treated previously with radiotherapy and chemotherapy which responded to therapy but had intact $1 \mathrm{p} / 19 \mathrm{q}$. Tumors in the series clustered according to $1 \mathrm{p} / 19 \mathrm{q}$ status regardless of whether primary or recurrent (Fig. 1) and prior therapy was not a main source of variation in PCA. Unsupervised hierarchical clustering of only primary tumors is given in Supplementary Data Fig. 1S (Suppl. Fig. 1S: http://www.qub.ac.uk/isco/JCO). Unsupervised hierarchical clustering using reliable probes from the Hs_SGC_Bv1 array showed similar results (data not shown).

\subsection{Genes associated with allelic imbalance in $1 p$ and $19 q$}

From the set of reliable probes, 166 probes (164 genes) were identified as two-fold significantly differentially expressed according to $1 \mathrm{p} / 19 \mathrm{q}$ status (Suppl. Table 2S: http://www.qub.ac.uk/isco/JCO). Of these, the majority (120) were down-regulated in tumors with $1 \mathrm{p} / 19 \mathrm{q}$ loss, with 17 genes located on $1 \mathrm{p}$ and 6 on $19 \mathrm{q}$. Functional analysis identified a number of biological processes that contained a significant number of differentially expressed genes (Table 2), including response to stress, inflammatory response, response to wound- 


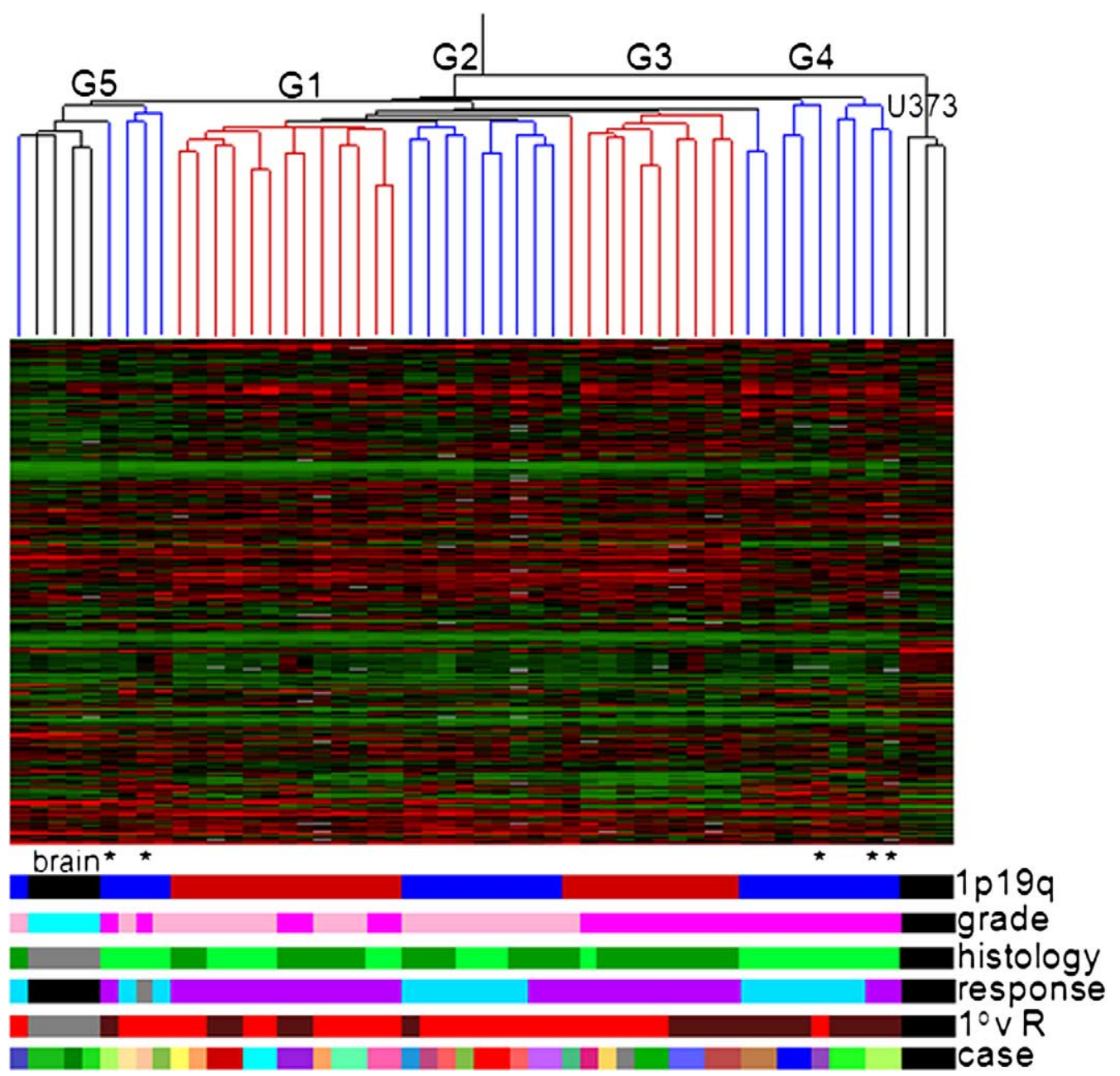

Fig. 1. Gene expression analysis. Hierarchical clustering was performed to cluster individual samples based on the similarity of their A probe-set gene expression profiles using Pearson correlation as a similarity measure with average linkage and the 3719 reliable probes. Samples are shown across the top and dendrogram branches are colored by $1 \mathrm{p} / 19 \mathrm{q}$ status: red, 1p/19q loss; blue, 1p/19q intact; black, non-neoplastic brain and U373 cell line samples. Genes are represented by rows and show expression levels relative to reference for each sample: red increased, green decreased and black similar expression. Status bars indicate: 1p/19q genotype $-\boldsymbol{\square} 1 \mathrm{p} / 19 \mathrm{q}$ loss, $\boldsymbol{\square}$ 1p/19q intact, $\boldsymbol{\square}$ non-neoplastic brain

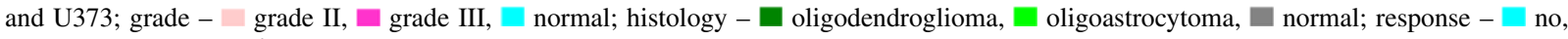

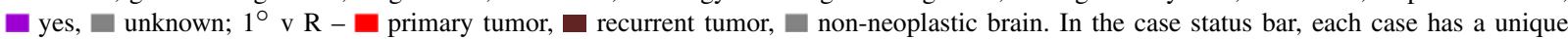
color illustrating expression profiles for multiple samples from the same case. Samples from tumors re-classified as glioblastomas with an oligodendroglial component following the WHO 2007 classification of CNS tumors are marked*.

ing, immune response, and response to chemical stimulus. Some metabolic processes were also identified as well as terms related to development and locomotory behavior.

Hierarchical clustering of samples using the 166 probes associated with $1 \mathrm{p} / 19 \mathrm{q}$ loss clearly separated tumors into two distinct clusters based on genotype (Fig. 2A). One tumor sample failed to cluster with other tumors with intact $1 p / 19 q$ and PCA showed that this sample did not associate with either genotype group (Fig. 2B).

\subsection{Genes associated with response to chemotherapy}

From the set of reliable probes, 96 probes (representing 94 genes) were identified as two-fold significantly differentially expressed with respect to response to chemotherapy (Suppl. Table 3S: http://www.qub.ac.uk/ isco/JCO). Of these, 68 probes were down-regulated and 28 probes were up-regulated in chemosensitive tumors, with 7 genes located on $1 p$ and 2 on 19q. Many processes identified during functional analysis were also those identified from analysis of $1 p / 19 q$ dif- 
Table 2

Biological processes containing genes differentially expressed between those tumors with 1p/19q loss and those without

\begin{tabular}{|c|c|c|c|c|c|}
\hline GO ID & Function name & Genes & Input genes & Genes on array & Corrected $p$-value \\
\hline GO:0009605 & Response to external stimulus & $\begin{array}{l}\text { NMI, ANXA1, BLNK, LY86, ALOX5, TLR2, CCR1, } \\
\text { CX3CR1, ABHD2, ADM, F5, DOCK2, SHROOM2 }\end{array}$ & 13 & 155 & $6.47 \mathrm{E}-04$ \\
\hline GO:0042221 & Response to chemical stimulus & CX3CR1, CCR1, DOCK2, SEPP1, PRDX6, TLR2, HSPA1L & 7 & 128 & 0.044 \\
\hline GO:0006950 & Response to stress & $\begin{array}{l}\text { NMI, ANXA1, BLNK, LY86, ALOX5, TLR2, CCR1, F5, CX3CR1, } \\
\text { ABHD2, ADM, HSPA1L, SEPP1, PRDX6, XRCC6BP1, XPA, CEBPG }\end{array}$ & 17 & 335 & 0.013 \\
\hline GO:0009611 & Response to wounding & $\begin{array}{l}\text { CX3CR1, ABHD2, ADM, NMI, } \\
\text { ANXA1, BLNK, LY86, ALOX5, TLR2, CCR1, F5 }\end{array}$ & 11 & 102 & $1.71 \mathrm{E}-04$ \\
\hline GO:0006954 & Inflammatory response & NMI, ANXA1, BLNK, LY86, ALOX5, TLR2, CCR1 & 7 & 70 & 0.005 \\
\hline GO:0006952 & Defense response & NMI, ANXA1, BLNK, LY86, ALOX5, TLR2, CCR1, CX3CR1, CEBPG & 9 & 114 & 0.005 \\
\hline GO:0002376 & Immune system process & $\begin{array}{l}\text { GEM, TNFRSF14, CEBPG, RGS1, IFI30, } \\
\text { CCR1, LAIR1, BLNK, LY86, TLR2, DOCK2 }\end{array}$ & 11 & 187 & 0.016 \\
\hline GO:0006955 & Immune response & $\begin{array}{l}\text { GEM, TNFRSF14, CEBPG, RGS1, IFI30, } \\
\text { CCR1, LAIR1, BLNK, LY86, TLR2 }\end{array}$ & 10 & 133 & 0.005 \\
\hline GO:0048513 & Organ development & $\begin{array}{l}\text { MATN3, CHRDL2, RUNX2, CEBPG, PPAP2B, SHROOM2, SEPP1, AFF2, } \\
\text { ID3, ADM, MYOZ1, GYPC, EDA2R, FABP5, EMP1, BLNK, FOXF2 }\end{array}$ & 17 & 307 & 0.007 \\
\hline GO:0009888 & Tissue development & EDA2R, FABP5, EMP1, CHRDL2, RUNX2 & 5 & 71 & 0.029 \\
\hline GO:0006629 & Lipid metabolic process & $\begin{array}{l}\text { PTGS1, ANXA1, FABP5, PPAP2B, NR2F2, APOC2, PLA2G4A, } \\
\text { PRDX6, ALOX5, AYTL1, STARD4, STAR, ADM }\end{array}$ & 13 & 241 & 0.016 \\
\hline GO:0006869 & Lipid transport & STARD4, APOC2, STAR, ATP8A2 & 4 & 26 & 0.005 \\
\hline GO:0008610 & Lipid biosynthetic process & ALOX5, PTGS1, STARD4, STAR, ADM, AYTL1, PLA2G4A & 7 & 98 & 0.016 \\
\hline GO:0006644 & Phospholipid metabolic process & PPAP2B, AYTL1, PLA2G4A, PRDX6 & 4 & 52 & 0.031 \\
\hline GO:0016477 & Cell migration & SHROOM2, PPAP2B, ABHD2, S100A2, DOCK2 & 5 & 66 & 0.023 \\
\hline GO:0007626 & Locomotory behavior & SEPP1, CX3CR1, CCR1, DOCK2 & 4 & 47 & 0.023 \\
\hline GO:0007166 & $\begin{array}{l}\text { Cell surface receptor linked signal } \\
\text { transduction }\end{array}$ & GEM, TNFRSF14, ANXA1, IL13RA1, MPL & 5 & 50 & 0.016 \\
\hline GO:0051090 & Regulation of transcription factor activity & ID3, CEBPG, EDA2R & 3 & 14 & 0.005 \\
\hline GO:0006366 & Transcription from RNA polymerase & FOXF2, SNFT, NMI, CEBPD, FUBP1 & 5 & 61 & 0.030 \\
\hline
\end{tabular}

Notes: Biological process GO terms identified from Onto-Express are listed if they contained at least three differentially expressed genes and had significant $p$-values $(p<0.05$, corrected for multiple testing). Input genes are the number of genes differentially expressed in the process and genes on array are the number of genes listed in the process that were also found in the set of reliable probes from the arrays. Boldfacing indicates those genes up-regulated in tumors with $1 \mathrm{p} / 19 \mathrm{q}$ loss, while genes in plain type are down-regulated in tumors with $1 \mathrm{p} / 19 \mathrm{q}$ loss. 

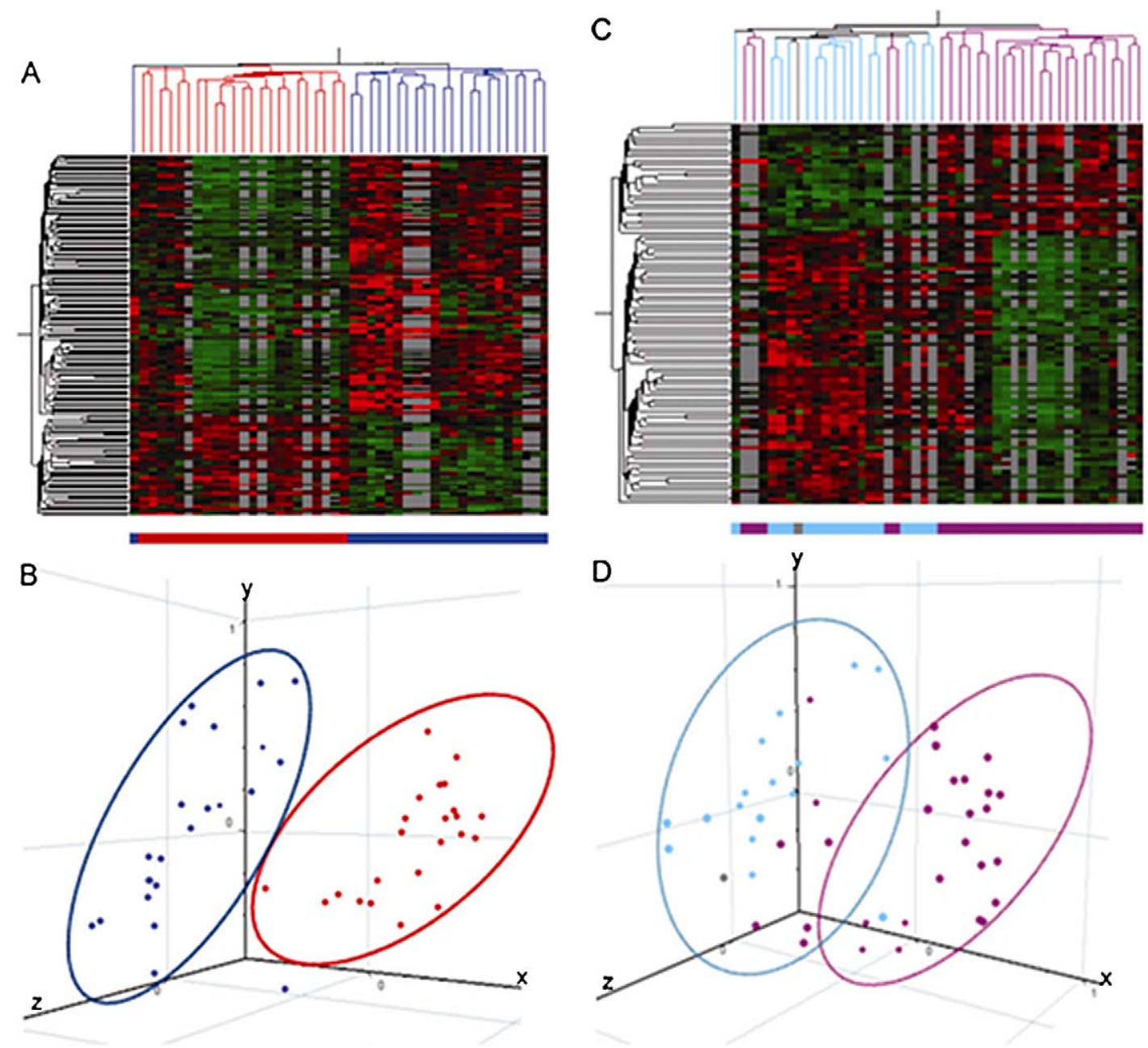

Fig. 2. Hierarchical clustering and PCA analysis. Hierarchical clustering and PCA based on the 166 probes differentially expressed between tumors with $1 \mathrm{p} / 19 \mathrm{q}$ loss and those without (A and B) and on the 96 probes differentially expressed between tumors that responded to therapy and those that did not (C and D). For $1 \mathrm{p} / 19 \mathrm{q}$ status samples are colored by: red, $1 \mathrm{p} / 19 \mathrm{q}$ loss; blue, $1 \mathrm{p} / 19 \mathrm{q}$ intact (A and B); and for response to therapy: purple, response; light blue, no response; grey, unknown (C and D). In hierarchical clustering samples are shown across the top and genes down the side. Genes are represented by rows and show expression levels relative to reference for each sample: red increased, green decreased and black similar expression. In B and D: $x, y$ and $z$ axes represent the 1 st, 2nd and 3rd principle component respectively.

ferentially expressed genes (Table 3). However, additional processes were obtained including those relating to transcription or signal transduction. Of the 96 probes identified as differentially expressed with respect to response to chemotherapy all bar 12 were also significantly differentially expressed with respect to the 1p/19q genotype.

Hierarchical clustering of samples using the 96 probes associated with chemosensitivity produced two main clusters, the first containing only tumors that responded to therapy and the second containing all non-responders and two responders with intact $1 \mathrm{p} / 19 \mathrm{q}$ (Fig. 2C). Most tumor samples were categorized based on their response to chemotherapy by PCA components one ( $x$-axis) and three (z-axis) (Fig. 2D). However, the separation was not as complete as that achieved for $1 \mathrm{p} / 19 \mathrm{q}$ status (Fig. 2B).

\subsection{Validation of differential gene expression by real-time PCR}

Thirteen genes (Table 4) were selected for further investigation and validation of expression results using real-time quantitative PCR and unamplified total RNA. Genes were considered for further investigation based on low $q$-values (SAM analysis), magnitude of fold 
Table 3

Biological processes containing genes differentially expressed between those tumors that responded and those that did not

\begin{tabular}{|c|c|c|c|c|c|}
\hline \multirow{3}{*}{$\begin{array}{l}\text { GO ID } \\
\text { GO:0009605 }\end{array}$} & \multirow{3}{*}{$\begin{array}{r}\text { Function name } \\
\text { Response to external stimulus }\end{array}$} & Genes & Input genes & Genes on array & Corrected $p$-value \\
\hline & & CX3CR1, BLNK, LY96, NMI, LY86, & \multirow[t]{2}{*}{10} & \multirow[t]{2}{*}{155} & \multirow[t]{2}{*}{$1.21 \mathrm{E}-04$} \\
\hline & & ALOX5, TLR2, HDAC4, DOCK2, SHROOM2 & & & \\
\hline GO:0042221 & Response to chemical stimulus & CX3CR1, DOCK2, SEPP1, TLR2, HSPA1L & 5 & 128 & 0.021 \\
\hline GO:0006950 & Response to stress & $\begin{array}{l}\text { XPA, SEPP1, HSPA1L, CX3CR1, BLNK, LY96, } \\
\text { NMI, LY86, ALOX5, TLR2, HDAC4 }\end{array}$ & 11 & 335 & 0.008 \\
\hline GO:0009611 & Response to wounding & CX3CR1, BLNK, LY96, NMI, LY86, ALOX5, TLR2, HDAC4 & 8 & 102 & $1.45 \mathrm{E}-04$ \\
\hline GO:0006954 & Inflammatory response & BLNK, LY96, NMI, LY86, ALOX5, TLR2, HDAC4 & 7 & 70 & $7.26 \mathrm{E}-05$ \\
\hline GO:0006952 & Defense response & BLNK, LY96, NMI, LY86, ALOX5, TLR2, HDAC4, CX3CR1 & 8 & 114 & $3.46 \mathrm{E}-04$ \\
\hline GO:0002376 & Immune system process & BLNK, HDAC4, GEM, LY96, IFI30, LAIR1, LY86, TLR2, DOCK2 & 9 & 187 & 0.002 \\
\hline GO:0006955 & Immune response & GEM, LY96, IFI30, LAIR1, BLNK, LY86, TLR2 & 7 & 133 & 0.003 \\
\hline GO:0048513 & Organ development & $\begin{array}{l}\text { HDAC4, CHRDL2, RUNX2, PPAP2B, SHROOM2, SEPP1, } \\
\text { AFF2, ID3, MYOZ1, GYPC, EDA2R, BLNK, EDNRB }\end{array}$ & 13 & 307 & $9.41 \mathrm{E}-04$ \\
\hline GO:0007399 & Nervous system development & $\begin{array}{l}\text { CABLES1, DOCK7, HDAC4, GFRA1, SHROOM2, } \\
\text { SEPP1, AFF2, EDNRB }\end{array}$ & 8 & 195 & 0.006 \\
\hline GO:0044267 & Cellular protein metabolic process & TLR2, FKBP5, HERC5, GYPC, MAN1C1, FAP & 6 & 1034 & 0.016 \\
\hline GO:0016477 & Cell migration & SHROOM2, EDNRB, PPAP2B, S100A2, DOCK2 & 5 & 66 & 0.002 \\
\hline GO:0007166 & Cell surface receptor linked signal transduction & $\begin{array}{l}\text { GEM, IL13RA1, LY96, GFRA1, CX3CR1, } \\
\text { FZD7, WASF2, EDNRB, NMU, TLR2, PPAP2B }\end{array}$ & 11 & 388 & 0.018 \\
\hline GO:0007186 & $\begin{array}{l}\text { G-protein coupled receptor protein } \\
\text { signaling pathway }\end{array}$ & CX3CR1, FZD7, WASF2, EDNRB, NMU & 5 & 163 & 0.048 \\
\hline GO:0007242 & Intracellular signaling cascade & $\begin{array}{l}\text { BLNK, HMHA1, EDA2R, NMI, GEM, EFCAB4B, } \\
\text { KIAA1244, FLJ21438, WASF2, EDNRB, CCNE1 }\end{array}$ & 11 & 465 & 0.049 \\
\hline GO:0016481 & Negative regulation of transcription & TGIF1, ID3, HDAC4, RUNX2 & 4 & 95 & 0.024 \\
\hline GO:0006366 & Transcription from RNA polymerase II promoter & NMI, SNFT, CEBPD, FUBP1, TGIF1, ID3, HDAC4 & 7 & 201 & 0.017 \\
\hline GO:0000122 & $\begin{array}{l}\text { Negative regulation of transcription } \\
\text { from RNA polymerase II promoter }\end{array}$ & TGIF1, ID3, HDAC4 & 3 & 35 & 0.006 \\
\hline GO:0007010 & Cytoskeleton organization and biogenesis & TMSB4X, DOCK2, WASF2, SHROOM2, MYOZ1 & 5 & 151 & 0.037 \\
\hline GO:0030036 & Actin cytoskeleton organization and biogenesis & DOCK2, WASF2, SHROOM2, MYOZ1 & 4 & 69 & 0.009 \\
\hline
\end{tabular}

Notes: Biological process GO terms identified from Onto-Express are listed if they contained at least three differentially expressed genes and had significant $p$-values $(p<0.05$, corrected for multiple testing). Input genes are the number of genes differentially expressed in the process and genes on array are the number of genes listed in the process that were also found in the set of reliable probes from the arrays. Boldfacing indicates those genes up-regulated in tumors that responded to therapy, while genes in plain type are down-regulated in such tumors. 
Table 4

Genes analyzed by real-time PCR

\begin{tabular}{|c|c|c|c|c|}
\hline Gene ID & Symbol & Gene name & Location & Biological role \\
\hline NM_004692 & INA & Internexin neuronal intermediate filament protein, alpha & $10 \mathrm{q} 24.33$ & Neurogenesis \\
\hline AK021826 & HDAC4 & Histone deacetylase 4 & $2 q 37.2$ & $\begin{array}{l}\text { Transcription; cell cycle; development; } \\
\text { inflammatory response }\end{array}$ \\
\hline NM_004964 & HDAC1 & Histone deacetylase 1 & $1 \mathrm{p} 34$ & $\begin{array}{l}\text { Apoptosis; inflammatory response; } \\
\text { chromatin modification }\end{array}$ \\
\hline NM_003870 & IQGAP1 & IQ motif containing GTPase activating protein 1 & $15 \mathrm{q} 26.1$ & Cytoskeleton; signal transduction \\
\hline NM_012333 & MYCBP & c-myc binding protein & $1 \mathrm{p} 33-\mathrm{p} 32.2$ & Regulation of transcription \\
\hline D28449 & ID3 & Inhibitor of DNA binding 3 & $1 \mathrm{p} 36.13-\mathrm{p} 36.12$ & Development \\
\hline NM_012446 & SSBP2 & Single-stranded DNA binding protein 2 & $5 q 41.1$ & Regulation of transcription \\
\hline M64497 & $\mathrm{NR} 2 \mathrm{~F} 2$ & Nuclear receptor subfamily 2 , group F, member 2 & $15 \mathrm{q} 26$ & Transcription; angiogenesis \\
\hline NM_003244 & TGIF1 & TGFB-induced factor (TALE family homeobox) & $18 \mathrm{p} 11.3$ & Transcription; development \\
\hline NM_005264 & GFRA1 & GDNF family receptor alpha 1 & $10 \mathrm{q} 26$ & $\begin{array}{l}\text { Cell surface receptor linked } \\
\text { signal transduction }\end{array}$ \\
\hline NM_000752 & LTB4R & Leukotriene B4 receptor & $14 \mathrm{q} 11.2$ & G-protein coupled signaling \\
\hline NM_004460 & FAP & Fibroblast activation protein, alpha & $2 q 23$ & Proteolysis and peptidolysis \\
\hline NM_016084 & RASD1 & RAS, dexamethasone-induced 1 & $17 \mathrm{p} 11.2$ & G-protein coupled receptor signaling \\
\hline NM_002582 & PARN & Poly(A)-specific ribonuclease (deadenylation nuclease) & $16 \mathrm{p} 13$ & RNA modification \\
\hline
\end{tabular}

change and their biological role, including any previous association with cancer. Significant differential expression was confirmed in 11/13 genes. The downregulation of IQGAPI, ID3, MYCBP, TGIF1, HDACl, $N R 2 F 2, S S B P 2, F A P$, and up-regulation of $H D A C 4$ and $I N A$ in tumors with $1 \mathrm{p} / 19 \mathrm{q}$ loss was confirmed (Fig. 3A). The array data identified GFRA1, HDAC4 and $L T B 4 R$ as significantly up-regulated and $S S B P 2$, $F A P$ and $R A S D 1$ as significantly down-regulated in tumors that responded to chemotherapy. Real-time PCR analysis confirmed these changes apart from $L T B 4 R$ and $R A S D 1$, although $R A S D 1$ had a trend toward down-regulation in the PCR data (Fig. 3B). Consistent expression of PARN across all samples was observed in the microarray data and real-time PCR analysis confirmed that it was not differentially expressed between groups (Fig. 3). If only primary tumors were included in the analysis of RT-PCR data IQGAPI, ID3, MYCBP, TGIF 1, HDAC1, NR2F2, HDAC4 and INA genes were significantly $(p<0.05)$ associated with $1 \mathrm{p} / 19 \mathrm{q}$ loss and GFRA1, HDAC4 and SSBP2 with response. Other genes significant in the series as a whole showed trends but did not reach statistical significance.

\section{Discussion}

The cohort investigated included all oligodendroglial subtypes and grades and was drawn from a series treated with a uniform therapeutic protocol in a single treatment centre. In the series $1 p / 19 q$ loss was associated with chemosensitivity and prolonged survival irrespective of histological subtype and grade or whether therapy was given to primary or recurrent tumors [45]. In this study, gene expression profiling data could be obtained following RNA amplification of total RNA from serial stereotactic biopsies. These samples were obtained by the minimally invasive surgical technique of frame-based serial stereotactic biopsy and such samples have not been used in previous glioma gene expression studies. Gliomas are recognised as being highly heterogeneous. Multiple biopsy samples in 17 cases were analyzed to investigate tumor heterogeneity and the majority of cases $(82 \%)$ showed greater similarity in gene expression profiles within tumors than between tumors. Similarly, Mehrian-Shai et al. reported clustering of multiple samples in 5/6 resected gliomas [23] and Liang et al. showed clustering of paired stereotactic biopsies from four glioblastomas, although the tissue sample size was greater than serial stereotactic biopsies [18]. In studies of other cancers, $80-90 \%$ of biopsy pairs clustered together $[4,26]$.

Unlike many studies of gliomas the majority of cases in our study were diagnosed by serial stereotactic biopsy and therapy given without prior debulking surgery. This has the advantage that response to therapy may be assessed radiologically, though several reports suggest that a more complete removal of diffuse gliomas is associated with better survival [30]. In addition, the diagnostic accuracy of stereotactic biopsy 

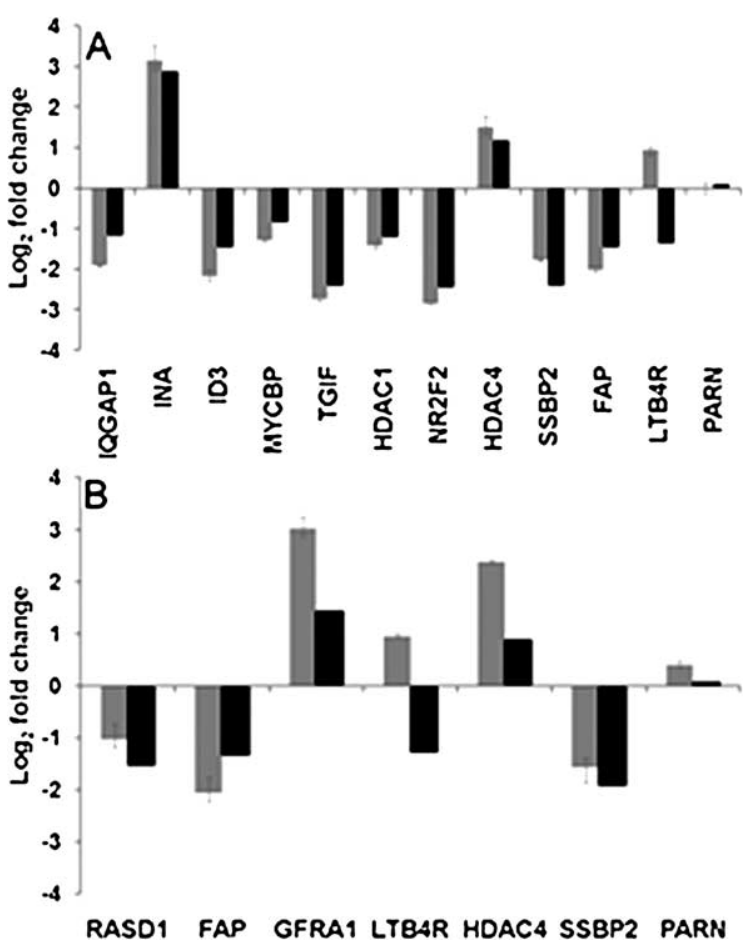

Fig. 3. Real-time PCR analysis of differentially expressed genes. (A) Samples grouped by $1 \mathrm{p} / 19 \mathrm{q}$ status, (B) samples grouped by response. Bars represent the mean relative gene expression of tumors with loss of $1 p / 19 q$ divided by the mean relative gene expression of tumors with intact $1 \mathrm{p} / 19 \mathrm{q}$ (A) or mean relative gene expression of responders divided by the mean relative gene expression of non-responders (B). This mean fold change in expression was $\log 2$ transformed. Following $\log 2$ transformation equal levels of gene expression have a value of zero and a two-fold difference has an absolute value of 1 . Grey bars ( $\square$ ), differential expression measured by real-time PCR. Black bars (ם), differential gene expression from microarray analysis of the same tumor samples available for PCR. All genes were significantly differentially expressed ( $p \leqslant 0.05$, Mann-Whitney $U$-test), except LTB4R and RASD1 for RT-PCR measurements and PARN for both analyses.

has been questioned with a risk of sampling errors in these histologically heterogeneous tumors which may lead to underestimation of malignancy grade. However, the multiple samples taken in a targeted trajectory in serial stereotactic biopsy has been associated with good diagnostic accuracy [36]. Cases in this study were diagnosed as oligodendroglial and treated with PCV chemotherapy before the introduction of the WHO 2007 classification of CNS tumors in which tumors previously diagnosed as oligoastrocytoma WHO grade III with necrosis would now be classified as WHO grade IV glioblastomas with an oligodendroglial component [31]. We have re-examined the histopathology of oligoastrocytomas previously classed as WHO grade III and 3 cases would now be classified as glioblastomas with an oligodendroglial component. These cases are indicated in Fig. 1 and do not cluster together.

Unsupervised hierarchical clustering identified groups of tumors of different grade and $1 \mathrm{p} / 19 \mathrm{q}$ status. Accumulation of molecular changes as gliomas progress from grade II to grade III has been well documented and distinct gene expression profiles for gliomas of different grade including oligodendrogliomas have been reported [32,46]. Given the large number of genes whose expression may potentially be altered by loss of two whole chromosomal arms, it is not unexpected that $1 \mathrm{p} / 19 \mathrm{q}$ loss has a dramatic effect on gene expression profiles, and tumors with and without these chromosomal losses cluster separately [7,25]. There was no significant difference in response to therapy or $1 \mathrm{p} / 19 \mathrm{q}$ status whether cases in the study were recurrent or primary tumors and gene expression profiles did not show preferential clustering dependent on therapy history. Comparison of primary and recurrent tumours may reveal gene expression differences due to clinical evolution or effects of previous radiotherapy, but we had insufficient recurrent cases for this analysis. Analysis of primary tumours only, gave similar conclusions to those derived from the whole series. Cases entered into this study included all oligodendroglial tumors treated with PCV during a defined time interval for which frozen tissue permitted gene expression analysis. One patient with an anaplastic oligoastrocytoma given PCV had been treated previously with radiotherapy and then given salvage chemotherapy. $1 p / 19 q$ status is not associated with response to salvage chemotherapy and this patient, whose tumor had intact $1 \mathrm{p} / 19 \mathrm{q}$, did show a partial response to PCV. Omitting this patient from the analysis did not change hierarchical clustering of the remaining cases, nor did it affect selection of genes for further investigation or change the conclusions of the study.

In this study, analysis of gene expression differences between tumors with $1 \mathrm{p} / 19 \mathrm{q}$ loss and those without these losses identified 164 genes at least twofold differentially expressed, with only 23 (14\%) located on the deleted chromosomal arms. Two previous studies have reported similar comparisons of genotype and gene expression in oligodendroglial tumors $[7,25]$. French et al. reported 60 genes associated with 1p/19q loss and Mukasa et al. reported 209 genes associated with $1 \mathrm{p}$ loss; only a few of the genes identified were differentially expressed in this study. However, many factors, both biological and techni- 
cal, vary between studies. French et al. [7] included mostly high-grade oligodendroglioma, while Mukasa et al. [25] studied a small series of tumors biased to low-grade samples with only a single oligoastrocytoma; both used Affymetrix arrays. In contrast we used oligonucleotide arrays on a wider spectrum of oligodendroglial neoplasms including approximately equal numbers of grade II and III, oligodendrogliomas and oligoastrocytomas. Many genes that were downregulated in tumors with $1 \mathrm{p} / 19 \mathrm{q}$ loss were not located on $1 p$ or $19 q$, supporting investigation of the full genome not just regions of loss. Low numbers of differentially expressed genes located on $1 \mathrm{p}$ or $19 q$ may reflect the two-fold cut-off used, as allelic loss may cause a two-fold decrease in expression of some genes which, taking error into account, may not pass the selection cut-offs. An increased proportion of differentially expressed genes on $1 p$ and $19 q$ were obtained when data was analyzed based on statistical significance without a defined cut-off (Suppl. Table 4S: http://www.qub.ac.uk/isco/JCO). In common with other studies of oligodendroglial tumours [11,13, 25,49 ], allelic imbalance of $1 \mathrm{p} 36$ and $19 \mathrm{q} 13$ was assessed using microsatellite markers which does not identify complete loss of chromosomal arms. It is now known that partial loss of $1 \mathrm{p}$ may occur in diffuse gliomas. Such partial losses often include the 1 p36 region and tend to have an opposite prognostic significance compared to the complete co-deletion of the $1 \mathrm{p}$ and $19 \mathrm{q}$ chromosome arms [12]. The fact that all tumors with $1 \mathrm{p} 36 / 19 \mathrm{q} 13$ loss in the present series showed response to chemotherapy suggests that most of these tumors carry complete co-deletion of $1 \mathrm{p}$ and $19 q$. One primary and one recurrent anaplastic oligodendroglioma, with loss of $1 \mathrm{p} 36$ in the absence of $19 q 13$ loss were classed as tumours without $1 \mathrm{p} / 19 \mathrm{q}$ loss and neither responded to therapy. Other techniques such as array $\mathrm{CGH}$ may be better suited to identifying complete loss but were not appropriate in this study due to the small size of samples.

Differential expression of selected genes associated with $1 \mathrm{p} / 19 \mathrm{q}$ loss was confirmed by real-time PCR. Of these, neuronal intermediate filament protein, alphainternexin (INA) and the scaffold protein IQGAPI have been investigated in other glioma studies [6,7], while the steroid/thyroid hormone receptor, $N R 2 F 2$ and the transforming growth factor beta inhibiting protein, $T G I F 1$, represent novel findings of differential expression in gliomas. Three genes on $1 \mathrm{p}$, down-regulated approximately two-fold, are of note. The helix-loophelix protein ID3 is involved in the regulation of tran- scription and development, and lower ID3 protein expression has been reported previously in oligodendrogliomas compared with astrocytomas [42]. Histone modification plays an important role in transcriptional regulation and inappropriate deacetylation may lead to repression of transcription. HDAC inhibitors can cause cell cycle arrest, differentiation and apoptosis and their role in the treatment of cancer, including glioma, is being investigated [16,29]. In this study HDACl expression was decreased in tumors with $1 \mathrm{p} / 19 \mathrm{q}$ loss in agreement with previous reports [7,25]. Differential expression of the $C-M Y C$ binding protein $M Y C B P$, which regulates transcriptional activity of $C-M Y C$, was also observed [34].

Gene expression analysis identified 94 genes associated with chemosensitivity of which 12 were not also associated with $1 \mathrm{p} / 19 \mathrm{q}$ loss. Clustering of tumors using these 94 genes identified a group of tumors that responded, but two tumors that responded failed to cluster with the other responders and both had intact $1 \mathrm{p} / 19 \mathrm{q}$. To date only one other study has related expression profiles of oligodendroglial tumors to chemosensitivity, which also failed to fully separate responders and non-responders through hierarchical clustering, although an improvement on response prediction based on $1 \mathrm{p}$ genotype was reported [7]. Coincidently this study examined the same number of patients $(n=28)$, but treatment was less consistent than in our cohort: two chemotherapy regimens were used (PCV and temozolomide) and patients had various degrees of resection. Likewise samples were from open resections and not reproducibly sampled as in our study. Their series was mostly high-grade tumors with $1 \mathrm{p} / 19 \mathrm{q}$ loss seen in $61 \%$ responders and two non-responders. A larger number of responders without $1 p / 19 q$ loss were included in their series and the overlap in the panels of differentially expressed genes for $1 p / 19 q$ loss and response seen in our study was not observed. The low number of responders with intact $1 p / 19 q$ in our study contributed to the difficulty in identifying genes associated with chemosensitivity independently of $1 \mathrm{p} / 19 \mathrm{q}$ genotype. The patient population in this study was also highly heterogeneous. While this is a limitation of the study this reflects our treatment practice and the clinical environment where molecular markers will need to be applied. The differential expression identified in this study requires confirmation in a larger independent series of oligodendroglial tumors preferably in a multicenter study because of the low incidence of these tumors.

Many of the transcripts-associated with response were involved in regulation of transcription and sig- 
nal transduction. Genes involved in signal transduction included GFRA1 and RASDI both of which affect the $M A P$ kinase pathway. GFRA1 is a membrane protein receptor for glial cell line-derived neurotrophic factor $(G D N F)$, a potent neuronal proliferation and differentiation factor. GFRA1 protein expression has been demonstrated in glioblastomas and other astrocytic tumors [47], but this is the first report of an association with response to therapy. The activator of G-protein signaling RASDl is expressed in many tissues and has been implicated in regulation of the circadian clock and immune response [3,19]. Transfection of RASD1 into cell lines in vitro inhibits growth and survival [38], however, there is no direct evidence of a role in human cancer or association with clinical outcome. Real-time PCR analysis also confirmed the association of transcription related genes $S S B P 2$ and HDAC4, as well as the serine proteinase $F A P$ with therapeutic response. Little is known about the function of $S S B P 2$, and there is little data on HDAC4 and FAP in glioma. FAP was first identified as a tumor promoting gene that may increase angiogenesis, but there is also evidence that under some conditions $F A P$ acts to suppress tumor growth [15,27]. In clinical samples high levels of FAP expression have been associated with poor outcome in colorectal and ovarian cancer but improved outcome in invasive ductal breast carcinoma $[1,10,50]$. While expression of FAP in human astrocytic tumors has been reported, with increased expression correlating with increased grade [33], further investigation of this gene and its association with chemosensitivity is needed to reveal its role in gliomagenesis.

We have demonstrated that gene expression profiling using serial stereotactic biopsy samples can be used to identify genes associated with $1 \mathrm{p} / 19 \mathrm{q}$ genotype or response to chemotherapy. Further studies will reveal if these genes can assist in the identification of patients with $1 \mathrm{p} / 19 \mathrm{q}$ loss, better prognosis or response to therapy, as well as the underlying biology of chemosensitivity. This may then empower us to selectively target those genes enhancing therapeutic efficacy even further.

\section{Acknowledgements}

This study was supported by Clatterbridge Cancer Research. We thank Prof. A. Cossins and Dr. B. Lane (University of Liverpool) for assistance with the microarray procedure including analysis, and Dr. L. Pazmany (University of Liverpool) for the RNA amplifi- cation procedure. We also thank the Human Genome Mapping project (HGMP) for providing oligonucleotide arrays and technical assistance.

\section{References}

[1] N. Ariga, E. Sato, N. Ohuchi, H. Nagura and H. Ohtani, Stromal expression of fibroblast activation protein/seprase, a cell membrane serine proteinase and gelatinase, is associated with longer survival in patients with invasive ductal carcinoma of breast, Int. J. Cancer 95 (2001), 67-72.

[2] J.G. Cairncross, K. Ueki, M.C. Zlatescu, D.K. Lisle, D.M. Finkelstein, R.R. Hammond, J.S. Silver, P.C. Stark, D.R. Macdonald, Y. Ino, D.A. Ramsay and D.N. Louis, Specific genetic predictors of chemotherapeutic response and survival in patients with anaplastic oligodendrogliomas, J. Natl. Cancer Inst. 90 (1998), 1473-1479.

[3] H.Y. Cheng, H. Dziema, J. Papp, D.P. Mathur, M. Koletar, M.R. Ralph, J.M. Penninger and K. Obrietan, The molecular gatekeeper Dexras1 sculpts the photic responsiveness of the mammalian circadian clock, J. Neurosci. 26 (2006), 12984-12995.

[4] S.J. Cleator, T.J. Powles, T. Dexter, L. Fulford, A. Mackay, I.E. Smith, H. Valgeirsson, A. Ashworth and M. Dowsett, The effect of the stromal component of breast tumours on prediction of clinical outcome using gene expression microarray analysis, Breast Cancer Res. 8 (2006), R32.

[5] S. Draghici, P. Khatri, P. Bhavsar, A. Shah, S.A. Krawetz and M.A. Tainsky, Onto-Tools, the toolkit of the modern biologist: Onto-Express, Onto-Compare, Onto-Design and OntoTranslate, Nucleic Acids Res. 31 (2003), 3775-3781.

[6] F. Ducray, A. Idbaih, A. de Reynies, I. Bieche, J. Thillet, K. Mokhtari, S. Lair, Y. Marie, S. Paris, M. Vidaud, K. HoangXuan, O. Delattre, J.Y. Delattre and M. Sanson, Anaplastic oligodendrogliomas with $1 \mathrm{p} 19 \mathrm{q}$ codeletion have a proneural gene expression profile, Mol. Cancer 7 (2008), 41.

[7] P.J. French, S.M. Swagemakers, J.H. Nagel, M.C. Kouwenhoven, E. Brouwer, P. van der Spek, T.M. Luider, J.M. Kros, M.J. van den Bent and P.A. Sillevis Smitt, Gene expression profiles associated with treatment response in oligodendrogliomas, Cancer Res. 65 (2005), 11335-11344.

[8] E.M. Grasbon-Frodl, F.W. Kreth, M. Ruiter, O. Schnell, K. Bise, J. Felsberg, G. Reifenberger, J.C. Tonn and H.A. Kretzschmar, Intratumoral homogeneity of MGMT promoter hypermethylation as demonstrated in serial stereotactic specimens from anaplastic astrocytomas and glioblastomas, Int. J. Cancer 121 (2007), 2458-2464.

[9] C. Hartmann, W. Mueller and A. von Deimling, Pathology and molecular genetics of oligodendroglial tumors, J. Mol. Med. 82 (2004), 638-655.

[10] L.R. Henry, H.O. Lee, J.S. Lee, A. Klein-Szanto, P. Watts, E.A. Ross, W.T. Chen and J.D. Cheng, Clinical implications of fibroblast activation protein in patients with colon cancer, Clin. Cancer Res. 13 (2007), 1736-1741.

[11] H. Huang, Y. Okamoto, H. Yokoo, F.L. Heppner, A. Vital, M. Fevre-Montange, A. Jouvet, Y. Yonekawa, E.N. Lazaridis, P. Kleihues and H. Ohgaki, Gene expression profiling and subgroup identification of oligodendrogliomas, Oncogene $\mathbf{2 3}$ (2004), 6012-6022. 
[12] A. Idbaih, Y. Marie, G. Pierron, C. Brennetot, K. Hoang-Xuan, M. Kujas, K. Mokhtari, M. Sanson, J. Lejeune, A. Aurias, O. Delattre and J.Y. Delattre, Two types of chromosome 1p losses with opposite significance in gliomas, Ann. Neurol. 58 (2005), 483-487.

[13] Y. Ino, R.A. Betensky, M.C. Zlatescu, H. Sasaki, D.R. Macdonald, A.O. Stemmer-Rachamimov, D.A. Ramsay, J.G. Cairncross and D.N. Louis, Molecular subtypes of anaplastic oligodendroglioma: implications for patient management at diagnosis, Clin. Cancer Res. 7 (2001), 839-845.

[14] M.D. Jenkinson, D.G. du Plessis, T.S. Smith, K.A. Joyce, P.C Warnke and C. Walker, Histological growth patterns and genotype in oligodendroglial tumours: correlation with MRI features, Brain 129 (2006), 1884-1891.

[15] T. Kelly, Fibroblast activation protein-alpha and dipeptidyl peptidase IV (CD26): cell-surface proteases that activate cell signaling and are potential targets for cancer therapy, Drug Resist. Updat. 8 (2005), 51-58.

[16] J.H. Kim, J.H. Shin and I.H. Kim, Susceptibility and radiosensitization of human glioblastoma cells to trichostatin A, a histone deacetylase inhibitor, Int. J. Radiat. Oncol. Biol. Phys. 59 (2004), 1174-1180.

[17] V.A. Levin, M.S. Edwards, D.C. Wright, M.L. Seager, T.P. Schimberg, J.J. Townsend and C.B. Wilson, Modified procarbazine, $\mathrm{CCNU}$ and vincristine (PCV 3) combination chemotherapy in the treatment of malignant brain tumors, Cancer Treat. Rep. 64 (1980), 237-244.

[18] Y. Liang, M. Diehn, N. Watson, A.W. Bollen, K.D. Aldape, M.K. Nicholas, K.R. Lamborn, M.S. Berger, D. Botstein, P.O. Brown and M.A. Israel, Gene expression profiling reveals molecularly and clinically distinct subtypes of glioblastoma multiforme, Proc. Natl. Acad. Sci. USA 102 (2005), 58145819.

[19] J.W. Lindsey, Dexamethasone-induced Ras-related protein 1 is a potential regulatory protein in B lymphocytes, Int. Immunol. 19 (2007), 583-590.

[20] K.J. Livak and T.D. Schmittgen, Analysis of relative gene expression data using real-time quantitative PCR and the 2(-Delta Delta C(T)) Method, Methods 25 (2001), 402-408.

[21] Z. Lwin, H.K. Gan and W.P. Mason, Low-grade oligodendroglioma: current treatments and future hopes, Expert Rev. Anticancer Ther. 9 (2009), 1651-1661.

[22] D.R. Macdonald, T.L. Cascino, S.C. Schold Jr. and J.G. Cairncross, Response criteria for phase II studies of supratentorial malignant glioma, J. Clin. Oncol. 8 (1990), 1277-1280.

[23] R. Mehrian Shai, J.K. Reichardt, H. Ya-Hsuan, T.J. Kremen, L.M. Liau, T.F. Cloughesy, P.S. Mischel and S.F. Nelson, Robustness of gene expression profiling in glioma specimen samplings and derived cell lines, Brain Res. Mol. Brain Res. 136 (2005), 99-103.

[24] P.S. Mischel, R. Shai, T. Shi, S. Horvath, K.V. Lu, G. Choe, D. Seligson, T.J. Kremen, A. Palotie, L.M. Liau, T.F. Cloughesy and S.F. Nelson, Identification of molecular subtypes of glioblastoma by gene expression profiling, Oncogene 22 (2003), 2361-2373.

[25] A. Mukasa, K. Ueki, S. Matsumoto, S. Tsutsumi, R. Nishikawa, T. Fujimaki, A. Asai, T. Kirino and H. Aburatani, Distinction in gene expression profiles of oligodendrogliomas with and without allelic loss of 1p, Oncogene 21 (2002), 3961-3968.
[26] J. Pramana, N. Pimentel, I. Hofland, L.F. Wessels, M.L. van Velthuysen, D. Atsma, C.R. Rasch, M.W. van den Brekel and A.C. Begg, Heterogeneity of gene expression profiles in head and neck cancer, Head Neck 29 (2007), 1083-1089.

[27] T. Ramirez-Montagut, N.E. Blachere, E.V. Sviderskaya, D.C. Bennett, W.J. Rettig, P. Garin-Chesa and A.N. Houghton, FAPalpha, a surface peptidase expressed during wound healing, is a tumor suppressor, Oncogene 23 (2004), 5435-5446.

[28] G. Reifenberger and D.N. Louis, Oligodendroglioma: toward molecular definitions in diagnostic neuro-oncology, J. Neuropathol. Exp. Neurol. 62 (2003), 111-126.

[29] T. Rikimaru, A. Taketomi, Y. Yamashita, K. Shirabe, T. Hamatsu, M. Shimada and Y. Maehara, Clinical significance of histone deacetylase 1 expression in patients with hepatocellular carcinoma, Oncology 72 (2007), 69-74.

[30] N. Sanai and M.S. Berger, Glioma extent of resection and its impact on patient outcome, Neurosurgery 62 (2008), 753-764; discussion 264-756.

[31] B.W. Scheithauer, G.N. Fuller and S.R. VandenBerg, The 2007 WHO classification of tumors of the nervous system: controversies in surgical neuropathology, Brain Pathol. 18 (2008), 307-316.

[32] R. Shai, T. Shi, T.J. Kremen, S. Horvath, L.M. Liau, T.F. Cloughesy, P.S. Mischel and S.F. Nelson, Gene expression profiling identifies molecular subtypes of gliomas, Oncogene 22 (2003), 4918-4923.

[33] J. Stremenova, E. Krepela, V. Mares, J. Trim, V. Dbaly, J. Marek, Z. Vanickova, V. Lisa, C. Yea and A. Sedo, Expression and enzymatic activity of dipeptidyl peptidase-IV in human astrocytic tumours are associated with tumour grade, Int. J. Oncol. 31 (2007), 785-792.

[34] T. Taira, J. Maeda, T. Onishi, H. Kitaura, S. Yoshida, H. Kato, M. Ikeda, K. Tamai, S.M. Iguchi-Ariga and H. Ariga, AMY1, a novel C-MYC binding protein that stimulates transcription activity of C-MYC, Genes Cells 3 (1998), 549-565.

[35] B. Tews, J. Felsberg, C. Hartmann, A. Kunitz, M. Hahn, G. Toedt, K. Neben, L. Hummerich, A. von Deimling, G. Reifenberger and P. Lichter, Identification of novel oligodendroglioma-associated candidate tumor suppressor genes in 1p36 and 19q13 using microarray-based expression profiling, Int. J. Cancer 119 (2006), 792-800.

[36] J. Tilgner, M. Herr, C. Ostertag and B. Volk, Validation of intraoperative diagnoses using smear preparations from stereotactic brain biopsies: intraoperative versus final diagnosis - influence of clinical factors, Neurosurgery 56 (2005), 257-265.

[37] V.G. Tusher, R. Tibshirani and G. Chu, Significance analysis of microarrays applied to the ionizing radiation response, Proc. Natl. Acad. Sci. USA 98 (2001), 5116-5121.

[38] G. Vaidyanathan, M.J. Cismowski, G. Wang, T.S. Vincent, K.D. Brown and S.M. Lanier, The Ras-related protein AGS1/RASD1 suppresses cell growth, Oncogene 23 (2004), 5858-5863.

[39] M.J. van den Bent, A.F. Carpentier, A.A. Brandes, M. Sanson, M.J. Taphoorn, H.J. Bernsen, M. Frenay, C.C. Tijssen, W. Grisold, L. Sipos, H. Haaxma-Reiche, J.M. Kros, M.C. van Kouwenhoven, C.J. Vecht, A. Allgeier, D. Lacombe and T. Gorlia, Adjuvant procarbazine, lomustine, and vincristine improves progression-free survival but not overall survival in 
newly diagnosed anaplastic oligodendrogliomas and oligoastrocytomas: a randomized European Organisation for Research and Treatment of Cancer phase III trial, J. Clin. Oncol. 24 (2006), 2715-2722.

[40] M.J. van den Bent, L.H. Looijenga, K. Langenberg, W. Dinjens, W. Graveland, L. Uytdewilligen, P.A. Sillevis Smitt, R.B. Jenkins and J.M. Kros, Chromosomal anomalies in oligodendroglial tumors are correlated with clinical features, Cancer $\mathbf{9 7}$ (2003), 1276-1284.

[41] M.J. van den Bent, M. Reni, G. Gatta and C. Vecht, Oligodendroglioma, Crit. Rev. Oncol. Hematol. 66 (2008), 262-272.

[42] D.A. Vandeputte, D. Troost, S. Leenstra, H. Ijlst-Keizers, M. Ramkema, D.A. Bosch, F. Baas, N.K. Das and E. Aronica, Expression and distribution of id helix-loop-helix proteins in human astrocytic tumors, Glia 38 (2002), 329-338.

[43] C. Walker, D.G. du Plessis, K.A. Joyce, D. Fildes, A. Gee, B. Haylock, D. Husband, T. Smith, J. Broome and P.C. Warnke, Molecular pathology and clinical characteristics of oligodendroglial neoplasms, Ann. Neurol. 57 (2005), 855-865.

[44] C. Walker, D.G. du Plessis, K.A. Joyce, Y. Machell, J. Thomson-Hehir, S.A. Al Haddad, J.C. Broome and P.C. Warnke, Phenotype versus genotype in gliomas displaying inter- or intratumoral histological heterogeneity, Clin. Cancer Res. 9 (2003), 4841-4851.
[45] C. Walker, B. Haylock, D. Husband, K.A. Joyce, D. Fildes, M.D. Jenkinson, T. Smith, J. Broome, D.G. du Plessis and P.C. Warnke, Clinical use of genotype to predict chemosensitivity in oligodendroglial tumors, Neurology 66 (2006), 1661-1667.

[46] M.A. Watson, A. Perry, V. Budhjara, C. Hicks, W.D. Shannon and K.M. Rich, Gene expression profiling with oligonucleotide microarrays distinguishes World Health Organization grade of oligodendrogliomas, Cancer Res. 61 (2001), 1825-1829.

[47] B. Wiesenhofer, G. Stockhammer, H. Kostron, H. Maier, H. Hinterhuber and C. Humpel, Glial cell line-derived neurotrophic factor (GDNF) and its receptor (GFR-alpha 1) are strongly expressed in human gliomas, Acta Neuropathol. 99 (2000), 131-137.

[48] R. Yamanaka, T. Arao, N. Yajima, N. Tsuchiya, J. Homma, R. Tanaka, M. Sano, A. Oide, M. Sekijima and K. Nishio, Identification of expressed genes characterizing long-term survival in malignant glioma patients, Oncogene 25 (2006), 5994-6002.

[49] S. Yip, A.J. Iafrate and D.N. Louis, Molecular diagnostic testing in malignant gliomas: a practical update on predictive markers, J. Neuropathol. Exp. Neurol. 67 (2008), 1-15.

[50] M.Z. Zhang, Y.H. Qiao, J.M. Nesland and Z.H. Suo, Expression of seprase in effusions from patients with epithelial ovarian carcinoma, Chin. Med. J. (Engl.) 120 (2007), 663-668. 


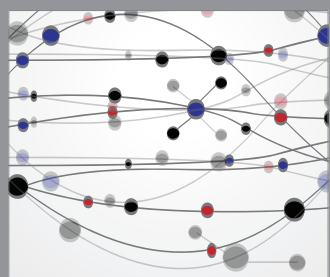

The Scientific World Journal
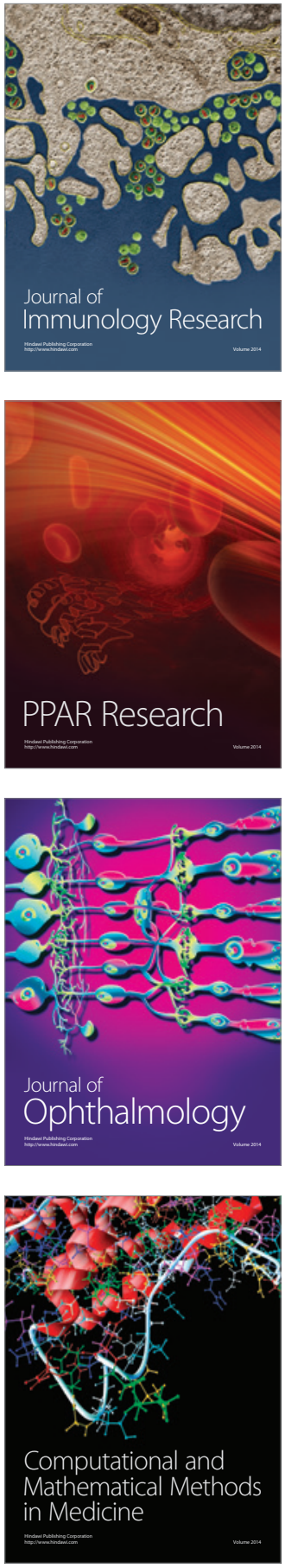

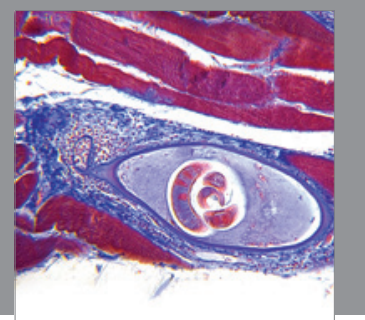

Gastroenterology

Research and Practice
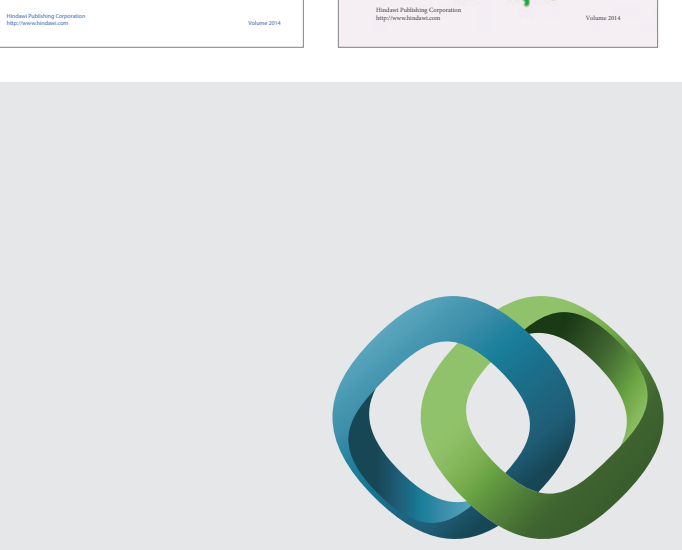

\section{Hindawi}

Submit your manuscripts at

http://www.hindawi.com
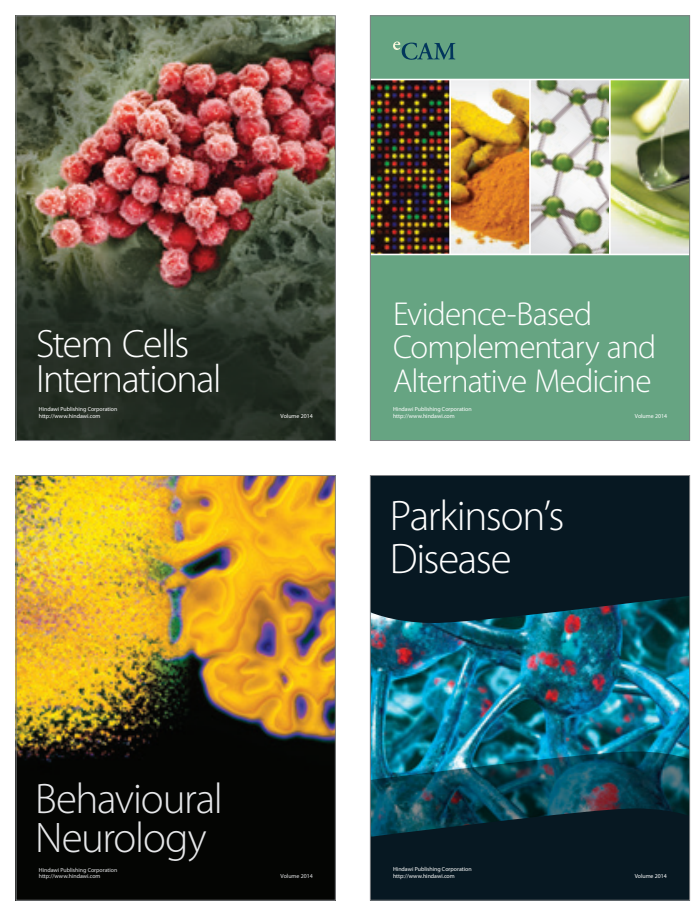

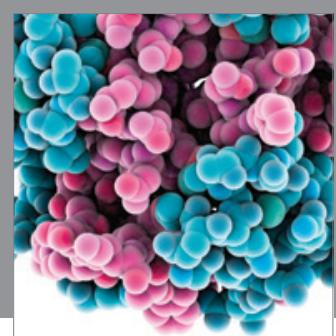

Journal of
Diabetes Research

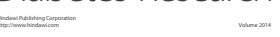

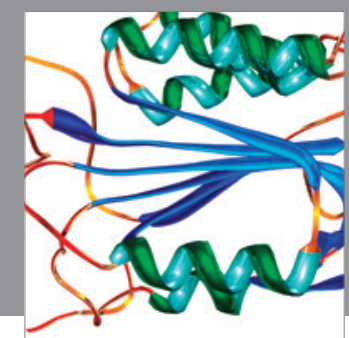

Disease Markers
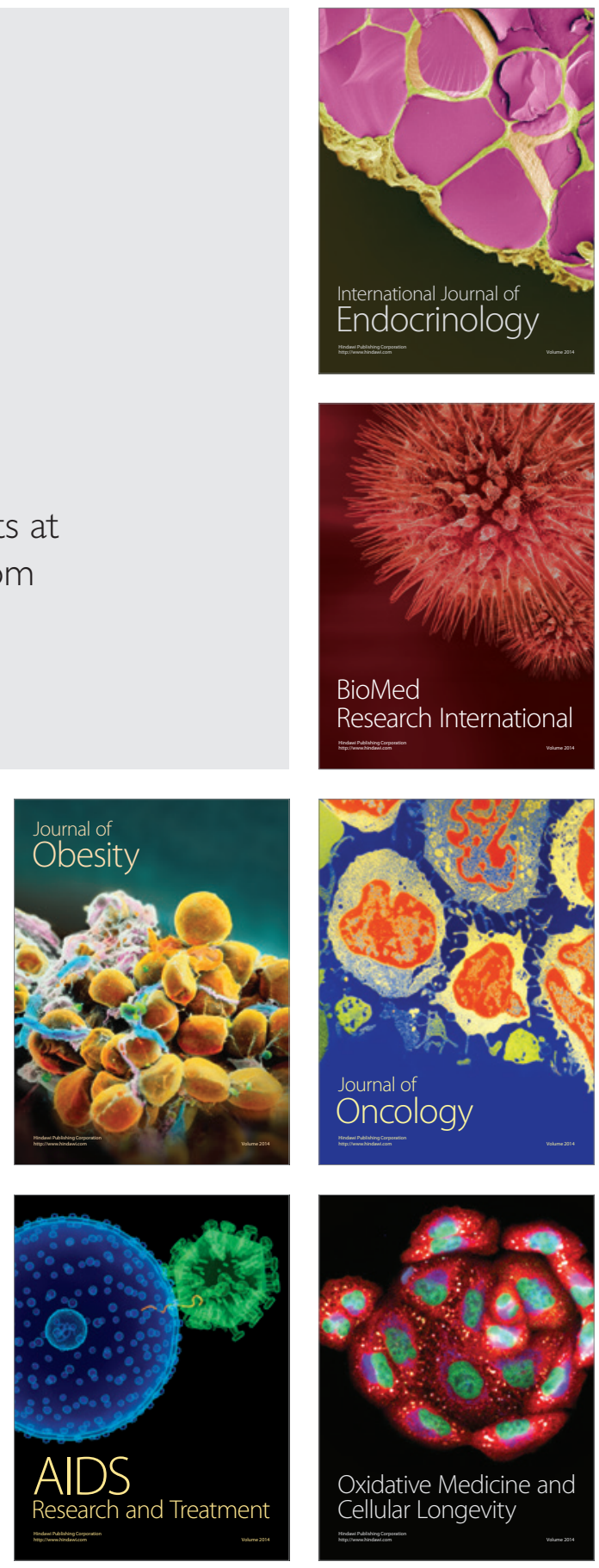